\title{
From codes of conduct to international framework agreements: contractualising the protection of human rights
}

\author{
Claire Marzo ${ }^{1}$
}

London School of Economics

The fundamental signification of a democratic constitution is to state that the power upon men, whatever it is, and whichever group or person exercises it, should have legally established limits. ${ }^{2}$

\begin{abstract}
$\underline{\text { Abstract }}$
This article analyses international framework agreements (IFAs) in the light of Polanyi's account of interventions to embed markets and thus regulate them. This special type of voluntary market regulatory arrangement that is shaped by multinational companies and international trade unions and constructed through the activities of the state is envisaged as a possible tool to embed liberalism even though several challenges must be taken into consideration.
\end{abstract}

\section{Introduction}

7 his article analyses IFAs in the light of Polanyi's account of interventions to embed markets and thus regulate them. An IFA is defined as an agreement between an international trade union and the management of the firm at the transnational level and which aims at the international activities of this firm. ${ }^{3}$ According to the European Commission it is:

an agreement comprising reciprocal commitments, the scope of which extends to the territory of several States and which has been concluded by one or more representatives of a company or a group of companies on the one hand, and one or more workers' organisations on the other hand, and which covers working and

1 British Academy Fellow, London School of Economics and Political Science. The author wishes to thank Bettina Lange for organising a workshop on Polanyi's relevance in Oxford and two anonymous reviewers for their helpful comments. All mistakes remain her own.

2 N Bobbio, "Per la difesa delle libertà democratiche nelle fabbriche"(1958) 1(January) Risorgimento 19.

3 "An agreement negotiated between a multinational company and a global union federation concerning the international activities of that company"; see International Confederation of Free Trade Unions (ICFTU), "Global Union Federations framework agreements with multinational enterprises", at www.icftu.org/displaydocument.asp? Index $=991216332 \&$ Language $=E N$ (last accessed 1 July 2011) and R-C Drouin, International Framework. Agreements: A study in transnational framework agreements: a study in transnational labour regulation ( $\mathrm{PhD}$ thesis, Montréal, 2005), p. 1. 
employment conditions and/or relations between employers and workers or their representatives. ${ }^{4}$

There are, to date, 66 IFAs. ${ }^{5}$ They have been negotiated by multinational companies (e.g. Ikea, Telefonica, Volkswagen, Rheinmetall, France Telecom) and international trade unions in very diverse sectors, such as agricultural, telecommunication, metal and automotive, and signed in many different countries (usually that of origin of the firm, and mainly, but not only, in Europe) ${ }^{6}$

These agreements are the trade unions' answer to the firms' codes of conduct. They aim to create a long-term relationship between the multinational firm and the international trade union. ${ }^{7}$ The main difference between these two types of texts lies in their enforcement. Whereas codes of conduct might not have any effect, IFAs can be enforced through diverse national collective agreements. ${ }^{8}$ They provide a framework to encourage the recognition of rights and negotiation. ${ }^{\text {? }}$

Three elements are at the heart of their definition: they enounce rights such as the right not to be discriminated against, working time rights and so on; they are negotiated; and they involve international sector trade unions. ${ }^{10}$ These three features present two advantages: IFAs give greater credibility to the strategies of firms' responsibility; and, because they are not unilateral (like most codes of conduct), they also create a certain legitimacy thanks to social dialogue. They can complement national regulations which might sometimes be seen as insufficient. Their transnational nature and their substantive or wide-ranging rights go beyond the mere cosmetic exercise and they show a growing will to protect fundamental social rights. ${ }^{11}$ Can these emergent modes of regulation lead to an alternative protection of labour and human rights? In Polanyi's terms, can IFAs be a tool embedding the market?

An IFA is a special type of voluntary market regulatory arrangement that is shaped by multinational companies and international trade unions and constructed through the activities of the state (through a system of property rights and contract enforcement through the courts). For this reason, they present a good opportunity to revisit the nature

4 European Commission staff working document, "The role of transnational company agreements in the context of increasing international integration”, COM (2008) 419, SEC (2008) 2155, 2 July 2008, p. 3. See also ICFTU, "Global Union Federations", n. 3 above.

5 See Accords transnationaux d'entreprise, Dialogue, droits, anticipation des restructurations, acteurs: une nouvelle perspective, 13 and 14 November 2008, Centre de conférence de Lyon, France.

6 E.g. see the Chiquite IFA signed in the United States in 2001. For a list, see Observatoire sur la Responsabilité sociétale des entreprises (ORSE), Directory for International Framework. Agreements Negotiations, June 2007, p. 57, available at www.orse.org/site2/maj/phototheque/photos/docs_an/IFA_june_2007.pdf (last accessed 1 July 2011).

7 Confédération internationale des syndicats libres (CISL), Guide syndical de la mondialisation (Bruxelles: CISL 2002), p. 133.

8 It would be wrong to think that IFAs are the future of CSR. Trade unions consider IFAs as an alternative to CSR not an evolution of it. The ILO also has a slightly more nuanced view of IFAs: "Although framework agreements are not CSR initiatives, they are often referred to in the CSR debate because they are one of the ways in which companies can express their commitment towards the respect of certain principles." See "International Framework Agreements: a global tool for supporting rights at work", www.ilo.org/global/about-the-ilo/press-and-media-centre/press-releases/WCMS_080723/langen/index.htm (last accessed 1 July 2011).

9 CISL, Guide syndicale, n. 7 above, p. 133.

10 Drouin, International Framework Agreements, n. 3 above, p. 250.

11 If fundamental rights are a generally regarded set of entitlements in the context of a legal system, wherein such system is itself said to be based upon this same set of basic, fundamental, or inalienable entitlements or rights, they are here understood as those protected at an international level by the Universal Declaration of Human Rights or the ILO. See, for instance, M Schmidt, Restructuring and Anticipation Dimension of Existing Transnational Agreements. Analysis and overview table, report prepared for the European Commission (Bruxelles: EC May 2008). 
and characteristics of state interventions in markets or, in other words, Polanyi's "great transformation" proposition. ${ }^{12}$

In order to study the relevance of Polanyi's account in today's world, the new mechanism that IFAs represent needs to be understood within his framework. This raises three questions.

1. First, what are IFAs regulating and can they regulate the market? There seems to be an interesting ambiguity about the role of IFAs in international law. On the one hand, IFAs are informal or soft law initiatives structured to limit the power of market actors. They therefore could be considered as embedding the market, e.g. in values such as consumer choice, employee needs and such like. On the other hand, IFAs are completely immune to public oversight or state intervention.

2. Second, how are IFAs regulated? A first impression is that they currently seem to exist in a realm of no hard law or market regulation and thus appear to be regulated by social rather than market forces.

3. Third, should IFAs be a means to regulate the market? In Polanyi's The Great Transformation, the "embedding of economic into social relationships" is defined as the embedding of economic relationships into the wider "public" interest of society as a whole. But it is unclear whether privately negotiated soft law frameworks reflect the interests of society at large (whether it is the UK, the EU, or the world as a whole), or simply the vested interests of established providers or dominant market players. In this light, it is also interesting to wonder whether IFAs could have a comparable effect to the Industrial Revolution. In 1944, in The Great Transformation, Polanyi argued that the Industrial Revolution was destructive as it entailed the disembedding of economic out of social relationships. Are IFAs promoting the disembedding or embedding of economic activity?

The project of "embedded liberalism" has already shown how corporate social responsibility (CSR) is a key method of furthering the Polanyian project. John Ruggie's work on the UN Global Compact has shown that "embedded liberalism" formed the principled basis of CSR under, for example, the aegis of the UN in the UN Global Compact. In the context of this vast literature that has developed from the Polanyian framework, the examination of IFAs in this article proposes a different interpretation and possible extensions/criticism of embedded liberalism itself.

Overall, IFAs could be a good way to embed or restrict the external effects of selfregulating markets within the framework of CSR. But this is under certain conditions (2 above): it involves asking:

a. whether IFAs can embed the market; and

b. how IFAs are themselves embedded within the existing system.

It also raises numerous challenges ( 3 above), particularly linked to the control that multinational firms have over these instruments in terms of: adjudication; content; and implementation.

\section{The wish: IFAs as a tool to embed liberalism}

Polanyi argued in the early 1940s in The Great Transformation for the self-regulation of economic activity both in a national and global context. Applying this approach leads to two

12 K Polanyi, The Great Transformation 2nd edn (Boston: Beacon Press 2001). 
conclusions: first, IFAs show how the economic world, that is multinational firms are turning towards a certain regulation of their social relations. We see that beyond the states' roles, private actors such as multinational firms can evolve towards designing CSR and the emergence of a new kind of regulation. In the field of CSR, the regulation of the market by private actors is more and more a reality. In other words, IFAs are a way to embed the market (see a above). Second, contracts, which are the central social relation and a feature of the market society, can enforce IFAs. In this sense, IFAs are embedded within the existing legal orders (b above).

\section{THE IDEA: IFAS AS A WAY TO EMBED THE MARKET}

Is the world becoming a market society? According to Polanyi's famous book The Great Transformation, the relationship between the market and society is inverted. ${ }^{13}$ Instead of the economy being embedded in social relations, social relations are embedded in the economic system.

This analysis is relevant to the current global economic crisis and thinking about new regulatory approaches. It might help in overcoming the distance between law and economy. A good example lies in employment and human rights law where an inherent tension between employees and employers had to be overcome. The traditional answer in labour law was enounced through the building of hard law around the protection of the employee, for instance in terms of industrial citizenship. ${ }^{14}$ For human rights lawyers, the solution went through international law and the recognition and enforcement by states of conventions protecting human rights. These answers appear less valid nowadays. Whether it is a choice of more or less powerful countries or a symptom of their weakness, a trend towards smaller state interference in the field of labour law emerges. The absence of appropriate regulation in a world more and more defined by globalised exchanges leads to rethinking the former protection mechanisms.

Globalisation is seen as the "intensification of worldwide relations which link distant localities in such a way that local happenings are shaped by events many miles away and vice versa". 15

Globalization has increasingly disconnected one single element - networks of production and finance - from what had been an overall system of institutional relations, and sent it off on its own spatial and temporal trajectory. This has produced ... disequilibria in the world political economy, which will persist unless and until the strictly economic sphere is embedded once more in broader frameworks of shared values and institutionalized practices. ${ }^{16}$

13 Polanyi, The Great Transformation, n. 12 above.

14 All around Europe, see A Supiot, M E Casas, J De Munck and P Hanau, Au-delà de l'emploi: transformations du travail et devenir du droit du travail en Europe: rapport pour la Commission des Communautés européennes (Paris: Flammarion 1999) and A Supiot, Homo juridicus (Paris: Seuil 2005), p. 183.

15 A Giddens as quoted in J Habermas, "The European nation state: its achievements and its limitations, on the past and future of sovereignty and citizenship" (1996) 9 Ratio Juris 125.

16 G Kell and J G Ruggie, "Global markets and social legitimacy: the case of the "global compact", paper presented at international conference, Governing the Public Domain beyond the Era of the Washington Consensus? Redrawing the Line Between the State and the Market (1999) available at www.unglobalcompact.org/NewsAndEvents/articles_and_papers/global_markets_social_legitimacy_york_ university.html. See also J G Ruggie, "International regimes, transactions and change: embedded liberalism in the postwar economic order" (1982) 36(Spring) International Organization 379-415; M Friedman, "The social responsibility of business is to increase its profits" in W M Hoffman and J Mills Moore (eds), Business Ethics: Readings and cases in corporate morality (New York: McGraw-Hill 1984). 
In international governance structures, there has been a significant expansion of global economic rule-making and the rights of global corporate actors have been secured, while global concerns, such as the environment, human rights or poverty, were left behind. Ruggie proposes a new version of Polanyi's embedding of the market in order to put forward an innovative response to precisely these kinds of imbalances. What he calls "the embedded liberalism compromise" was a solution in the $1930 \mathrm{~s}^{17}$ and could be of help nowadays.

According to Ruggie, this movement already appears in the interplay between two sets of key actors in the global economy, transnational corporations and transnational nongovernment organisations (NGOs) in the institutional venue of the UN through the initiative of the Global Compact and in $\mathrm{CSR}^{18}$. He contends that this dynamic interplay provides great potential for attempts to bridge the imbalance between economic globalisation and the governance structures that it has left behind.

The Global Compact challenges individual corporations and representative business associations to demonstrate good global corporate citizenship by embracing nine principles in the areas of environment, labour and human rights, and by advocating stronger UN organisations in those and related areas. ${ }^{19}$ Described as a Faustian bargain, it offers the advantage of protecting human rights and non-economic interests as well as attracting corporations for practical reasons (one-stop shopping reducing transaction costs for multinational firms interested in these processes) and legitimacy reasons (for acting on universally agreed principles).

It also appears in CSR movements. Because of this geographical reconstruction that globalisation allows, firms are turning towards new methods of self-regulation. CSR is progressively built. CSR is an interesting contemporary attempt to socialise economic relationships. ${ }^{20}$ Defined as the "voluntary integration by firms of social and environmental concerns into the commercial activities and their relationships with stakeholders", 21 it is in concrete terms conveyed by numerous texts. ${ }^{22}$ The main ones are voluntary codes of conduct and newer ones such as IFAs.

Because of their bilateral nature, IFAs are an interesting tool for dialogue between multinational companies and NGOs and/or international trade unions. It is a way to give a voice to non-economic actors and tackle the identified imbalance. It is also a way to, following the terms used by John Ruggie, embed "global market forces in shared values and institutionalized practices, and bridging the gaps in global governance structures". ${ }^{23}$

\section{THE INTEREST: EMBEDDING IFAS OR THEIR INSERTION WITHIN THE EXISTING LEGAL ORDERS}

The interest of relying on IFAs to embed the market is that they can, more or less easily, be inserted within the existing legal orders or, in other words, be embedded within broader

17 Kell and Ruggie, "Global markets", n. 16 above.

18 G Whelan, J Moon and M Orlitzky, "Human rights, transnational corporations and embedded liberalism: what chance consensus?" 87 Journal of Business Ethics 367.

19 See www.unglobalcompact.org/ (last accessed 1 July 2011).

20 This can also be associated with Ruggie's recent suggestion that a "new consensus" has formed, or is forming, around his "protect, respect and remedy" framework. See Whelan et al., "Human rights", n. 18 above.

21 Commission of the European Communities, "Communication from the Commission concerning corporate social responsibility: a business contribution to sustainable development", 2 July 2002, COM(2002) 347 final.

22 Several types of internal and external codes have been identified. See F McLeay, "Corporate codes of conduct and the human rights accountability of transnational corporations: a small piece of a larger puzzle" in O De Schutter, Transnational Corporations and Human Rights (Oxford/Portland, Oregon: Hart 2006), pp. 219_ 40, and B Teyssie, "La négociation collective transnationale d'entreprise où de groupe" (2005) 11 Droit Social 982. 
social relations, thus creating a network around the market. This embeddedness is not always seen as a blessing by multinational firms. The question from the company's viewpoint is whether the IFAs represent any danger of formal legal liability. ${ }^{24}$

A preliminary question is to understand what the risks are for a multinational firm which adopts an IFA. ${ }^{25}$ In case of a breach of the rights of the employees, ${ }^{26}$ the risks are legal, financial and moral and can be sanctioned in different frameworks. ${ }^{27}$ After signing the IFA, the multinational firm is supposed to enforce the obligations it contains, which increases the number of obligations in different frameworks and countries and the risks of violating them. The firm has to find a balance between its liability and the preservation of its economic interests. Because IFAs do not fit into the national legal categories, it might be thought that media exposure is the greatest risk, but legal risks should not be underestimated.

I will focus on legal liability risks. They raise two problems: from the point of view of the firm, the aim is to avoid being condemned on the basis of an IFA. From the point of view of the employees or the international federations, the aim is to oblige the firms to comply with the commitments they undertook. The point is to avoid factual or legal immunities. ${ }^{28}$

The main risk for the firm is to be condemned. It incurs criminal, ${ }^{29}$ civil, ${ }^{30}$ or contractual liability. If there is no clause conferring jurisdiction, national law is applied. The applicable law, the jurisdiction and the characterisation of the agreement have to be determined. The legal consequences of the action will depend on the country in which the

23 Kell and Ruggie, "Global markets", n. 16 above.

24 H Genn, M Partington and S Wheeler, Law in the Real World: Improving our understanding of how law works. final report and recommendations (London: Nuffield Inquiry on Empirical Legal Research, Nuffield Foundation 2006); W Streeck, "Social science and moral dialogue: critical forum, toward a new socio-economic paradigm" (2003) 1 Socio-Economic Review 126.

25 Also see "Introduction" in T Lewens (ed.), Risk: Philosophical perspectives (London and New York: Routledge 2007).

26 The terms "worker" and "employee" are used interchangeably. Some of the IFAs use worker not employee, but some also use employee.

27 Informal meeting between the firm Arcelor Mittal and the ILO.

28 M-A Moreau, "Négociation collective transnationale: réflexions à partir des accords-cadres internationaux du groupe Arcelor Mittal” (2009) 1 Droit social 93.

29 See O De Schutter, "Les affaires Total et Unocal, Complicité et extraterritorialité dans l'imposition aux entreprises d'obligations en matière de droits de l'homme" in Annuaire français de droit international LII (Paris: CNRS Éditions 2006); A J Wilson, "Beyond Unocal: conceptual problems in using international norms to hold transnational corporations liable under the Alien Tort Claims Act" in De Schutter, Transnational Corporations, n. 22 above, pp. 43-72; O De Schutter, "L'incrimination universelle de la violation des droits sociaux fondamentaux", Cellule de recherhe interdisiplinaire en droits de l'homme (CRIDHO), Working Paper 2005/05; T Keithley, "Does the National Labor Relations Act extend to Americans who are temporarily abroad?" (2005) 105 Columbia Law Review 2135. Examples of extra-territorial liability were found in Doe I v Unocal Corp. 395 F3d 932 (9th Cir 2002) and Cour d'appel de Versailles, Total, 11 January 2005 in which multinational firms were accused of violations of human rights in Myanmar by a group of employees. They contended that they had been constrained to forced labour by the authorities of this country on behalf of the companies. The federal district court of the United States identified a case of civil liability related to the lack of respect of international obligations by the firms. They are not related to IFAs since the obligations in these cases were fundamental rights protected by international texts such as the ILO conventions, but IFAs, when they exist, can present an added interest linked to contractual liability. K Sontag, "La justiciabilité des droits de l'homme à l'égard des sociétés transnationale" in L Boy, J-B Racine, F Siiriainen, Droit économique et droits de l'bomme (Bruxelles: Larcier 2009), pp. 569-640.

30 See n. 29 above and E Decaux, "La responsabilité des sociétés transnationales en matière de droits de l'homme" (2005) 4 Revue des sciences criminelles 789; M Delmas-Marty, Globalisation économique et universalisme des 
action has started. Without analysing the law of each country, ${ }^{31}$ one can generally distinguish between civil law and common law. In common law, the first condition put to a legal action is that of personal jurisdiction. Defined in the United States as the power of a court to judge, it is twofold: the in personam jurisdiction related to the claimant and the in rem jurisdiction related to the litigation. ${ }^{32}$ Extensive interpretations of these conditions have sometimes been seen where the American courts accepted to judge disputes quite disconnected from American law in cases of violation of human rights. ${ }^{33}$ In civil law and European Union law, according to the Brussels 2 regulation, ${ }^{34}$ the applicable law is that of the defendant, of the workplace or of the place of hire if the former one is unclear. The competent judge is that of the applicable law. ${ }^{35}$ Finally, an international contract can provide for the application of another law, ${ }^{36}$ raising the question of the application to a foreign law by national judges.

Then, one has to determine who will be able to claim in respect of these obligations. Beyond classical principles about the interest in bringing the case in front of the judge, United States courts recognise the possibility to start class actions. ${ }^{37}$ This trend, which is starting to raise interest in Europe, is not generalised yet. ${ }^{38}$

Finally, the legal characterisation of the agreement can be interpreted in two ways: either the agreement is seen as soft law and it cannot be invoked in front of a court, or it has a legal value which should be determined. In the absence of a legal status recognised in private international law, ${ }^{39}$ the IFA should be fitted within existing law categories or texts. Depending on the judge, these agreements can be considered as contracts, gentlemen's agreements, international customs, or labour law collective agreements. ${ }^{40}$ In each of these cases, the agreement creates obligations for the employers and for the employees.

\section{IFAs as contracts}

droits de l'homme (Montréal: Thémis 2004) ; M. Delmas-Marty, "Aplanir le terrain de jeu" (2005) 4 Revue des sciences criminelles 735 .

31 In order to limit the field of application of a broad subject, I will not examine the law of each country to determine what exact procedure should be followed to engage the responsibility of multinational firms. Instead, I will rely on the common principles to all legal orders to understand the choices offered to the firm.

32 See A Belatchev, Jurisdiction in USE $v$ Noriega: With special reference to the Honecker case (Uppsala: Iustus Förlag 2000).

33 See H Muir Watt, "L'universalité de la compétence juridictionnelle nationale: quelles stratégies pour les acteurs (USA/Europe)" in M-A Moreau (ed.), Le juge et les relations de travail dans le contexte de la mondialisation de l'économie (Paris, Dalloz 2010) and C Forcese, "Globalizing decency: responsible engagement in a era of economic integration” (2002) 2 Yale Human Rights \& Development Law Journal 1.

34 See the Brussels Convention, Regulation 2201/2003 of 27 November 2003 concerning jurisdiction and the recognition and enforcement of judgments in matrimonial matters and the matters of parental responsibility, repealing Regulation (EC) No 1347/2000, Article 14.

35 According to Regulation (EC) No 593/2008 of the European Parliament and of the Council of 17 June 2008 on the law applicable to contractual obligations (Rome I).

36 See n. 64 below, the arbitration clause.

37 See the contribution of E Loquin, "L'arbitrage, mode de règlement des différends internationaux relatifs aux droits de l'homme ou aux droits sociaux fondamentaux" in Moreau (ed.), Le juge, n. 33 above.

38 See the Green Paper of the European Commission, Access of Consumers to Justice and the Settlement of Consumer Disputes in the Single Market, COM(93) 576, 16 November 1993, p. 64: In 1993, eight of the 12 member states gave consumer associations the right to sue a defendant in order to protect the collective interests of consumers.

39 D Be, "A report on the European Commission initiative for a European framework for transnational collective bargaining" in K Papadakis (ed.), Cross-border Social Dialogue and Agreements, An emerging global industrial relations framework? (Geneva: ILO 2008), ch. 9, available at www.ilo.org/wcmsp5/groups/public/_-dgreports/—dcomm/—-publ/documents/article/wcms_093471.pdf (last accessed 1 July 2011), and Drouin, International Framework Agreements, n. 3 above. 
In civil law and in common law, a contract, whether it is internal or international, ${ }^{41}$ creates rights and obligations for each party. It has a binding value, thanks to the principle of pacta sunt servanda, and it creates a duty of good faith. ${ }^{42}$ This is particularly interesting for IFAs as they, if they are decided to be contracts, will gain these characteristics.

The contract is defined, in civil law, as a concurrence of wills in order to create legal obligations. ${ }^{43}$ In order for the contract to be valid, consents must have been exchanged, ${ }^{44}$ the parties should have the ability to contract, and the object of the contract should be lawful. It should also have a cause and a fair contractual price. 45

In common law countries, a similar definition of the contract is given, this is the interest of this characterisation. A contract is two promises: an offer and an acceptance. ${ }^{46}$ The offer is an intimation, by words or conduct, of a willingness to enter into a legally binding contract, and which in its terms expressly or impliedly indicates that it is to become binding on the offeror as soon as it has been accepted by an act, forbearance, or return promise on the part of the person to whom it is addressed. ${ }^{47}$ The acceptance is the expression by words or conduct, of assent to the terms of the offer in the manner prescribed or indicated by the offeror. ${ }^{48}$ The offer and the acceptance must be certain and an intention to create contractual relations must be shown. When all these conditions are fulfilled, the contract binds the parties. It has a compulsory legal value and it produces legal effects between the parties. ${ }^{49}$ This very simplistic doctrinal reading of contracts should be nuanced because, as Hugh Collins indicated, implicit dimensions of contract have fundamentally rewritten the doctrinal rule book and especially how common law judges identify contracts. These sociallegal re-readings of the doctrinal rule book blur the boundaries between soft law initiatives and contract law. This opens the path to a bigger impact by IFAs.

A contractual obligation is recognised, under common law, under several conditions: first, the IFA should contain a clear enough promise so that an employee can reasonably believe that an offer was made; second, the agreement must be disseminated or announced in such a way that the employees can consider it an offer; third, the employees must have accepted the offer explicitly or implicitly. Their consent can be expressed by the fact that they started or kept working after they discovered the new policy. ${ }^{50}$ An analysis of the letter and the spirit of the agreement must be made. An implicit contract can also be discovered if several criteria - such as the duration of employment, the actions and communications of the employer, the practices and policies of the employer, the attention given to the

40 See I Daugareilh, "Le juge, acteur de la responsabilité sociale de l'entreprise: interrogation à partir du contentieux relatifs aux codes de conduite" in Moreau (ed.), Le juge, n. 33 above.

41 The distinction relies on a cross-border element which gives the contract its international characteristics.

42 This is not true in all jurisdictions as judges in the UK have been resistant to the idea of good faith. See A Burrows, A Casebook on Contract (Portland, Oregon: Hart 2007).

43 It should be kept in mind that this is not the only definition of contracts. See A Benabent, Droit civil 11th edn (Paris: Domat Droit privé, Montchréstien 2007), p. 12. The contract is defined as a concurrence of will in order to create obligations or to transfer rights from one person to the other ("Le contrat est défini comme un accord de volonté en vue de créer des obligations ou de transférer des droits patrimoniaux d'une personne à une autre”): see also B Starck, H Roland and L Boyer, Obligations vol. 2, 5th edn (Paris: Litec 1995), p. 1.

44 It is based on the autonomy of the will, see Starck et al., n. 43 above, p. 410.

45 "Public order", ibid. n. 43 above, ch. 3.

46 A contract consists of an actionable promise or promises. These promises are called the offer and the acceptance, see J Beatson, Anson's Law of Contract (Oxford: OUP 2002), p. 27.

47 Ibid. p. 37.

48 Ibid. p. 37.

49 Contrary to common law, which states that a contract cannot bind a third party, civil law gives a compulsory effect toward third parties when they have agreed it or when they gave a mandate to the contracting parties. 
promises of the employer and the practices of the sector - are fulfilled.

Despite the theoretical interest of this construction, there is no example to this day of such an interpretation, but twice already claimants proposed to interpret similar texts (in these cases, a code of conduct) as contracts. In the Wal-Mart case, Chinese, Bengali, Indonesian and Nicaraguan workers decided on 13 September 2005 to sue the multinational firm Wal-Mart in the Court of Los Angeles in the United States alleging that it had not respected the obligations created by its code of conduct towards the employees of its subcontracting firms. The question was raised whether this code could be considered to be a contract. ${ }^{51}$ Wal-Mart had obliged all its sub-contractors to sign the code and to display it in the language of the country in all the centres of production. The claimants claimed that in return Wal-Mart had an obligation to ensure that their working conditions corresponded with the code's requirements. In this particular case, the code of conduct was not interpreted as a contract between the firm and its sub-contractors. ${ }^{52}$ Such a judgement favours a restrictive interpretation, but it does not clearly exclude this hypothesis.

In a second case, the same code of conduct and the same firm (Wal-Mart) were challenged in a German court. There, the difference of legal order, of applicable law and of state of mind of the judges has led to the recognition of a contract. But it must be said that the conflict was raised in other circumstances: because the multinational firm was ready to dismiss an employee who did not respect the code, thus, in other words, indicating that it was bound by this text, the German judge recognised a contract. ${ }^{53}$ This difference might be explained by the fact that, in the first case, sub-contractors submitted a claim whereas, in the German case, it was an employee. The proximity of the link might explain the outcomes of the cases. Depending on the legal framework in which the dispute is analysed, this solution can be true.

This interpretation of a soft law code of conduct as a binding contract is very encouraging as it opens the way to determining the possible impact of IFAs in existing legal orders. It is a way to embed the multinational companies' choices. Other alternatives can also be contemplated.

\section{IFAs as other legal instruments}

An IFA can also be characterised as three different legal texts which create legal obligations and must be implemented by a multinational company: a unilateral commitment, a customary rule or a collective agreement (in the labour law meaning).

First, in civil law as in common law, a unilateral commitment or a gentleman's agreement can create actionable obligations. Saying that an IFA could be characterised as a unilateral commitment (a gentleman's agreement) is not contradicting the earlier observation according to which IFAs, contrary to codes of conducts, are not unilateral, ${ }^{54}$ but rather providing a legal analysis of the potential legal characterisation of an IFA. It can be legally considered interchangeably as a unilateral commitment or as a gentleman's agreement. In this case, a firm would be sanctioned if it committed to respect some standards and then

See, for instance, the French Civil code, Article 1984 and following.

50 Weber Shandwick Worldwide v Reid, No 05 C 709, 2005 US Dist LEXIS 144482, at 6 (ND III 12 May 2005).

51 It was a "class action complaint for injunctive Relief and Damages". See K-E Kenny, "Code or contract: whether Wal-Mart's code of conduct creates a contractual obligation between Wal-Mart and the employees of its foreign suppliers" (2007) 27 Northwestern Journal of International Law and Business 453.

52 US District Court for the Central District of California, Jane Doe I et al. v Wal-Mart Stores Inc., Case No CV 05 7307 AG (MANx), 30 March 2007. An appeal could still take place, see www.iradvocates.org/; see S L Cummings, "Critical legal consciousness in action" (2007) 120 Harvard Law Review 62; answering O Lobel, "The paradox of extralegal activism: critical legal consciousness and transformative politics" (2007) 120 Harvard Law Review 937; C Estlund, "Something old, something new: governing the workplace by contract again” (2007) 28 Comparative Labor Law and Policy Journal 351. 
violated them. This hypothesis was found in Kasky v Nike. 55 In this case, a unilateral declaration ${ }^{56}$ had been made by the firm and the US judge considered that this bound its author thanks to commercial law and misleading advertising. ${ }^{57}$ This concept, used in consumer law, has one inconvenience: it transforms labour law into consumer law. It reverses the classical tensions: the claimant is not anymore the worker, but the consumer. In other words, the workers becomes object (and not any more subject) of the protection. This is a very interesting point as we see that the outcome is not the only issue. In this case, the probability of the success of the claim is reduced by the impossibility for the workers of submitting a claim. They need to find the support of consumers - highlighting the growing role of media - in order to find protection.

Second, the court can also decide that the IFA is a customary rule which creates binding legal effects if the agreement has been applied for a long period of time. This approach was chosen by a Spanish court. ${ }^{58}$

A third solution is to see in the IFA a national collective agreement (in the labour law meaning) or a clause of this agreement. This implies that the IFA fulfils the criteria of a collective agreement in national law. The agreement then derives its legal value from the law of the state. ${ }^{59}$ A classical tool of labour law, it can lead to the condemnation of the multinational firm which does not respect its obligations and it gives the workers the necessary tools to protect their rights. However, this hypothesis is not very reliable because collective agreements have very different legal values across the world. Even within the European Union there is (at the moment) ${ }^{60}$ no sufficient uniformity to imagine building common rules. ${ }^{61}$ This tool would have been useful as it would allow the employees to ask the representatives to protect their rights, founding the whole protection on the classical functioning of collective bargaining and labour law. It would also create a parallel between the signatories of the agreement and the persons responsible for its application and enforcement as, in both situations, the multinational firm ${ }^{62}$ and the international federation ${ }^{63}$ would be present.

53 Kenny, "Code or contract", n. 51 above, p. 462.

54 See n. 3 above.

55 Marc Kasky v Nike Inc., 02 CDOS 3790, No S087859.

56 The declaration could be found on the firm's website and stated the will of the firm to comply with its code.

57 See A Sobczak, "Legal dimensions of international framework agreements in the field of corporate social responsibility” (2007) 62 Relations Industrielles/Industrial Relations 466, p. 477.

58 See M-L Morin, "Le juge français et quelques contentieux significatifs" in Moreau (ed.), Le juge, n. 33 above.

59 See A Mengel, "Ramification of appeals judgment on an employer's code of ethics", 30 January 2006, see www.martindale.com/labor-employment-law/article_Wilmer-Cutler-Pickering-Hale-Dorr LLP_215328.htm on a decision of 14 November 2005, by the Court of Appeal of Work of Dusseldorf. This judgment largely confirms the local court's decision and limits the ability of an employer to implement an ethics code without first consulting with the works council - a process known as "co-determination" in Germany. Under German law, all general rules governing the conduct of employees in the workplace (Ordnungsverhalten) must be agreed upon by the works council. By contrast, employers are generally free to impose rules about work performance (Arbeitsverbalten) without prior consent by the works council. See www.wilmerhale.com/ publications/whPubsDetail.aspx?publication=3053 (last accessed 1 July 2011).

60 See an initiative of the European Commission which gave rise to the Edouardo Ales report on transnational collective agreements: S Laulom, "Passé, présent et futur de la négociation collective transnationale" (2007) 5 Droit Social 623.

61 See Article 151 and following of the Treaty on the Functioning of the European Union.

62 Management at international and national levels. The chief executive officer often signs the agreement.

63 On the employees' side, the signature can be given by international trade unions, the European works council (which sometimes raises a question about its legitimacy when non-European countries are involved) and 
If theoretical propositions to fit IFAs into the international and national legal orders are numerous, the actual tackling of this issue by courts is relatively rare. But, even so, multinational firms prefer to prepare for all risks.

This concern of multinational companies for the legal consequences of IFAs shows a first step towards embedding their behaviours within social relations, here represented by international federations and non-economic organisations. But this embeddedness also raises challenges.

\section{The challenge: IFAs between non-economic actors' participation and control of transnational companies}

The main advantage of IFAs is that they are a step towards embedding the transnational companies' behaviours within a social system. In other words the market or economy is embedded in social relations. A question remains: does the firm not have too much say in the IFAs' adjudication and content? In Polanyi's proposal, the embedding of economic relationships is into the wider "public" interest of society as a whole. It is unclear whether privately negotiated soft law frameworks reflect the interests of society at large and whether the companies' management can/should play this role. On the other hand, models need to align with reality. And it makes sense that it is the dominant market players, or the most powerful actors, who should be granted a major role in the protection of non-economic interests. To determine whether this compromise is acceptable, I will focus on the IFAs' adjudication, content and implementation mechanisms.

What makes it difficult to assess IFAs' relevance is that they are built on a paradox: whereas one could expect to find minimal participation of the firm in the IFA, we find a paradoxical evolution towards their increasing responsibility. The paradox is that firms try to extract their agreements from national justice by granting rights and procedures, but the unavoidable risk of litigation pushes them to limit these rights. This paradox is triple: i) concerning the choice of adjudication or dispute conflict resolution mechanism, firms foresee the risk of adjudication, thus they make a conscious choice, but try to limit its impact by choosing the least activist judges; ii) concerning the choice of content, firms protect a growing number of rights but in a limited field of application; and, finally, iii) concerning the choice of implementation mechanism, agreements contain procedural guarantees, but their implementation can be imprecise.

\section{THE CHOICE OF ADJUDICATION}

Although it is for the defendant to choose to which judge to go to and in our case for the employees to decide whether or not to go to a judge, the stipulation of a mediator or adjudicator allows the firm to anticipate more easily the consequences of hypothetical litigation. The legal culture of the firm has an impact on this choice. One should distinguish between formal adjudication through a court of law and informal alternative dispute resolution mechanisms. Often, the IFA contains a clause conferring jurisdiction or an arbitration clause. Exceptionally, they create an original internal dispute settlement mechanism. One should understand that the goal of these IFAs is to avoid any litigation. ${ }^{64} \mathrm{In}$ a first phase, the agreements establish internal regulations, but they also foresee the conflict. This is why arbitration has a wide role. ${ }^{65}$ Four alternative solutions should be considered.

national trade unions (which raises a question of coordination and representation in the different countries). See working document, European Commission, "Mapping of transnational texts negotiated at corporate level”, EMPL F2 EP/bp 2008 (D) 14511, Brussels, 2 July 2008. 
First, a clause conferring jurisdiction is a provision which gives jurisdiction to the court specifically referred to in the agreement. ${ }^{66}$ Most agreements which have such a clause usually refer to national law. ${ }^{67}$ The referral can be implicit or explicit. For instance, it could be attached to a European works council agreement. The applicable laws are thus to be found in this agreement. The main advantage of the referrals is the participation of an independent and autonomous judge. The firms are nonetheless limited by national justice and its delays.

Second, in order to avoid such disagreements, firms can also call arbitrators. Instead of clauses conferring jurisdiction on courts, arbitration clauses aim at removing litigation from state courts to put it in front of an arbitral tribunal. The parties can derogate from the rules of international jurisdiction. The clause is interpreted independently from the international contract in which it is drafted. It is per se applicable. ${ }^{68}$ The clause can also confer jurisdiction to non- or para-jurisdictional tribunals. ${ }^{69}$

Third, the newest solution, and directly linked to IFAs, is the internalisation of conflicts. This technique, sometimes used in national law, ${ }^{70}$ is particularly interesting in transnational situations. To this day, five scenarios of internalisation by multinational firms have been counted. They aim is to avoid a trial by finding a solution to the complaint within the firm. In all cases, this procedure is about giving a right to any employee to inform the firm of any behaviour violating the agreement. ${ }^{71}$ When a dispute is identified, it will be taken into account by designated members within the firm. The representatives of the European works council can be in charge of it, in collaboration with the management. ${ }^{72}$ It can also be a "joint global committee". This hypothesis is usually preferred when international trade unions or European federations are signatories. They are then in charge of the settlement of the litigation in collaboration with the management. ${ }^{73}$

A fourth solution is to call a panel of independent experts. Ad hoc organs usually include, again, trade unions and management. ${ }^{74}$ NGOs can also be asked to participate. The bilateral dialogue becomes trilateral and civil. Some authors talk about a trialogue. ${ }^{75} \mathrm{~A}$ similar and last option is the creation of a joint committee. ${ }^{76}$ In the best cases, one can imagine the participation of an international organisation. For instance, the International Labour Organisation (ILO) could name a member in charge of settling conflicts. Its institutional dimension would give it legitimacy. But this last hypothesis has never been set up.

64 See R-C Drouin, "Procédures de règlement interne des différends de droit du travail dans l'entreprise multinationale", in Moreau (ed.), Le juge, n. 33 above.

65 See E Loquin, "L’arbitrage”, n. 37 above.

66 With the exception of "imperative competences" or "compétences impératives", see Y Loussouam, P Bourel and P De Vareillers-Sommieres, Droit international privé 8th edn (Paris: Précis, Dalloz 2004), pp. 611-13.

67 For instance, the agreement signed by Arcelor explicitly refers to Luxemburg law whereas the Suez and Total agreements refer to French law.

68 Loussouam et al., Droit international privé, n. 66 above, pp. 611, 614.

69 Reports and complaints to the ILO and the Social Charter of the Council of Europe will not be considered here: see Daugareilh, "Le juge", n. 40 above.

70 For instance in the UK, S Deakin, "The role of collective agreements and social dialogue in large construction projects including Terminal 5, Heathrow Airport", Industrial Law Society evening meeting, 26 November 2009, London.

71 For instance, Renault.

72 For instance, EADS, Generali, Suez in 2007 and Total in 2004.

73 The Schneider Electric agreement states that "the EMF and the General Management shall seek an amicable solution for these disagreements within a reasonable period of time and in a spirit of cooperation".

74 For instance, Ford 2000, Danone 2001. 
In all cases, the advantage of these procedures is that they involve directly the different social partners. The IFA rules and procedures are "owned" by all of the partners. The management of the enterprise avoids national or international justice. At the same time, the employee or the sub-contractor sees his/her complaint taken into account. Nonetheless, these mechanisms create a risk of instituting a parallel justice. If the presence of trade unions should ensure a better protection of workers, one can still fear that these actors have less weight in negotiation than the management. This protection is even less certain if one considers that firms try to avoid the attention of the national courts. The solutions proposed are arrived at through negotiations and compromises. ${ }^{77}$ Although a positive aspect is that they allow for flexibility and the discovering of original and case-by-case solutions, it is also negative in that this flexibility might lead to less solid protection. The choice of the judge must be strengthened by the choice of wording of the agreement.

\section{THE CHOICE OF CONTENT}

Four fundamental rights - the prohibition of forced labour, child labour and discrimination and the recognition of the freedom of association - are usually recognised in IFAs. Like many codes of conduct, ${ }^{78}$ IFAs often mention the ILO, sometimes its 1998 declaration. ${ }^{79}$ Professor Wilke recently counted fundamental rights in these agreements. He concluded that the right not to be discriminated against occurs in 90 per cent of the agreements, the freedom of association appears in 95 per cent of them, and the prohibition of child labour and the prohibition of forced labour appear in 90 per cent of them. ${ }^{80}$ Beyond these standards, the rights vary depending on the material needs of the parties. Some clauses are about the living conditions of workers and of their families. Other agreements are about environmental protection. Others are about the health and security of employees and wages. Then the questions of working time, harassment and training are raised. ${ }^{81}$ Finally, an emerging subject is that of information and consultation of workers ${ }^{82}$ and restructuring processes. ${ }^{83}$

The scope of application of these agreements is nonetheless limited. It is limited by the choice of the wording and by the circle of beneficiaries. Often, the agreements will state that rights will be protected "as far as possible". This flexibility in the agreement is a way of releasing the firm from its obligations. Also, the rights are very rarely defined, ${ }^{84}$ which gives a broader margin of interpretation to the judge trying to discover the meaning of the obligation, but also allows the firm to choose the most restrictive meaning. Firms often produce guidelines which aim at explaining and restricting the effect of the IFAs. Most IFAs do not raise the protection given by national labour law, but create a responsibility of the firm as to the respect of these norms. Thus, the protection is a private regulation, without

75 I De Jesus Butler, "Non-governmental organisations' participation in the EU law-making process, the example of social non-governemental organisations in the Commission, Parliament and Council" (2008) 14 European Law Journal 558.

76 In French, un comité paritaire.

77 See Drouin, "Procédures de règlement", n. 64 above.

78 Organisation for Economic Co-Operation and Development, see www.oecd.org/document/12/ 0,3343,en_2649_34135_35532108_1_1_1_1,00.html (last accessed 1 July 2011).

79 P Wilke and K Schütze, "Background paper on international framework agreements for a meeting of the restructuring forum devoted to transnational agreements at company level”, Hamburg, 2 June 2008, p. 8. Out of 59 IFAs, a reference to the ILO appears in $73 \%$ of the cases. A reference to the ILO conventions appears in $58 \%$ of the cases. A reference to the UN Declaration appears in $27 \%$ of the cases. Global Compact is mentioned in $19 \%$ of the cases.

80 Ibid.

81 Drouin, "Procédures de règlement", n. 64 above, p. 256.

82 See the Directive 2009/38/EC of the European Parliament and of the Council of 6 May 2009 on the 
any intervention of the state, but based on national labour law and implemented by the existing labour institutions. ${ }^{85}$

Another limit is that the scope of application of the agreement is often limited to an illdefined group. The group, in its functional or economic meaning, is often legally divided. Thus, the protection of some dependent employees is sometimes non-existent. ${ }^{86}$ To this day, only 73 per cent of sub-contractors enjoy the protection of an IFA. ${ }^{87} \mathrm{~A}$ definition of the term "sub-contractor" could help avoid the gaps of this protection. A solution could be to impose the respect of the IFA as a condition of the pursuance of the contract. But the reality of working conditions does not always make it possible. Thus, techniques of training and learning are often preferred. In the face of these uncertainties, procedural guarantees reinforce the implementation of the agreement to a certain extent.

\section{THE CHOICE OF IMPLEMENTATION MECHANISMS}

Contrary to codes of conduct, IFAs provide for detailed provisions about the implementation of the agreements. Often, a procedure of monitoring is proposed: the implementation is not limited to signs at the place of work, it gives a real role to national and local trade unions. A new process of dissemination of the rules through trade unions takes place. ${ }^{88}$

An annual assessment is undertaken to ensure the good implementation of the agreement. A procedural logic based on representation in joint committees appears. ${ }^{89}$ The provisions can be very precise and innovative. They are articulated with the labour law of the country in which the agreement is applied and the joint committees are in charge of this process.

However, when the power of control of these committees is uncertain, the agreement might be deprived of any real implementation. In order to avoid this lack of implementation, the agreement should be directly applicable in the country or implemented by the trade unions of this country. ${ }^{90}$ Then, a procedure would ensure its enforceability. Several techniques are available: first, if the agreement contains vague provisions about procedure, the question of its binding or voluntary effect can be raised. ${ }^{91}$ Second, it can be stated that only the local management will be in charge of its implementation. ${ }^{92}$ Third, the implementation can be placed in the hands of the local management and the employees' representatives without any other explanation. ${ }^{93}$ Other agreements are implemented by collective bargaining. ${ }^{94}$ Finally, many agreements provide that they should be implemented in all branches of the firm. ${ }^{95}$ In all cases, decentralisation of decision-making is the aim. This is double-edged: it allows for a greater adaptation of the agreement to the local situation, but this flexibility can also be its weak spot. In this way, a nuanced image emerges.

establishment of a European Works Council or a procedure in Community-scale undertakings and Community-scale groups of undertakings for the purposes of informing and consulting employees.

83 Wilke and Schütze, "Background paper", n. 79 above, p. 7.

84 It could be argued that a definition given in an international text might suffice, but it is not always true.

85 Drouin, "Procédures de règlement", n. 64 above, p. 256.

86 Sobczak, "Legal dimensions", n. 57 above, p. 473.

87 Wilke and Schütze, "Background paper", n. 79 above.

88 It could be noted that sometimes the implementation mechanism and the conflict resolution mechanism will be the same - like the joint committees, for example.

89 For instance, Arcelor, accord santé, M-A Moreau, "Négociation collective transnationale", n. 28 above.

90 For instance, Total Platform agreement of 2004. See Schmidt, Restructuring, n. 11 above.

91 For instance, the Rhodia agreement and the Suez social charter do not contain any provision about procedures. 
The implementation of the procedures, whether ensured by the firm itself or afterwards by courts, remains variable. ${ }^{96}$

IFAs have detailed implementation procedures. They give unions a real role (global, national and local). But guarantees are weakened when when there is uncertainty about who controls the committees. Procedures should ensure the enforceability of the IFA. But decentralisation of decision-making is double-edged: it is more adapted to local conditions but can possibly be a weakness because of power imbalances between management and local unions.

It appears in the end that, contrary to what one might expect, the company plays a major role in enforcement. In order to remove the risk of litigation, companies grant rights and procedures. But the risk this introduces then leads them to impose restrictions. This creates a twin paradox: first, that there are a growing number of rights but their application is restricted; and, secondly, that agreements contain procedural guarantees, but implementation is undermined by a lack of precision.

\section{Conclusion: towards a Polanyian model}

The use of IFAs, as well as a rising demand for a CSR framework at the European level, ${ }^{97}$ shows the need for firms to evolve a transparent and comprehensible legal framework. It encourages some optimism as to the emergence of transnational regulation. But the use of the IFA is also paradoxical. From the point of view of the firm, risk is unavoidable. Because of this, firms systematically try to make the risk visible in order to limit it. From the point of view of the worker, the ability of firms to establish their plants in particular countries according to the occurrence of risk prevents a majority of workers from efficiently protecting their rights. Where there is division over the approach to be followed by the trade union community, some international federations have concluded that a strategy of cooperation and "constructive engagement" will yield better results than confrontation. At the same time, there is no doubt that, without the threat of confrontation, firms would be less likely to engage in the process. In this sense, IFAs are an interesting way to embed economy into social relations.

In conclusion, not only was Polanyi's work of interest because it raises the idea of embedding the economy into social relations, but also because it pushes towards evolutions. Somehow, there is a certain inevitability about Polanyi's thesis which will result in i) a recognition of the centrality of contracts and ii) further steps to embed the company's social choices in the regulatory framework.

Embedding the company's social choices in the regulatory framework can take several forms and this opens the way to further research. Several theoretical ways to do this could be explored. One is the reinforcement of the role of international organisations. Second, an international court or arbitrator could give more visibility to litigation in this field ${ }^{98}$ and calls for CSR frameworks and the increasing use of paralegal jurisdictions ${ }^{99}$ indicate that this is a consideration. Third, the development of a soft law framework and the

\footnotetext{
92 For instance, the Arcelor, EADS 2005, Generali agreements.

93 For instance, Renault.

94 For instance, PSA and EDF.

95 For instance, Generali, Suez 1998, Danone 1992 and Lukoil.

96 L R Price, "International framework agreements: a collaborative paradigm for labor relations" in De Schutter,
} 
recognition of the international legal personality of multinational enterprises ${ }^{100}$ could also go hand-in-hand with the research as these developments will ultimately embed social values and relationships within the economic system. Nonetheless, given the current stiff opposition by governments and multinational companies to extending the regulatory framework, this could all turn out to be a case of misplaced optimism. But that is the object of another study.

Transnational Corporations, n. 22 above, pp.241-60.

97 A Lebescond, "Responsabilité sociétale: de l'art et de la manière de moraliser les enterprises" (2009) Lexbase Hebdo, Edition Sociale 335.

98 An improved role for the ILO has also been imagined, see Drouin, "Procédures de règlement", n. 64 above.

99 See Daugareilh, "Le juge", n. 40 above.

100 The recognition of the international legal personality of multinational enterprises can also be considered as a 